http://jmscr.igmpublication.org/home/ ISSN (e)-2347-176x ISSN (p) 2455-0450 crossref DOI: https://dx.doi.org/10.18535/jmscr/v7i11.73

\title{
Relationship between serum HbA1C level with CRP level in patients with diabetic foot ulcer \& Newly detected Diabetes Mellitus
}

\author{
Authors \\ Kezia Blessinda $\mathbf{R}^{1}$, Lekshmi G.S ${ }^{2}$, Sreekumari.S ${ }^{3}$, Ajith Kumar.P.V ${ }^{4}$, \\ R. Dayananda Babu ${ }^{5}$ \\ ${ }^{1}$ PG Department of Biochemistry, ${ }^{2,3,5}$ Professor, ${ }^{4}$ Associate Professor
}

Objectives

\section{Primary}

- To find out whether serum HbA1c level in a patient with Diabetic foot ulcer and newly diagnosed diabetes correlates with their CRP values during that period of time.

\section{Secondary}

- To find out if glycemic control can decrease the CRP value in a diabetic foot ulcer patient and newly diagnosed diabetes patients.

\section{Materials \& Method}

Study Design: Observational study

Study Setting: Sree Gokulam Medical College \& Research Foundation

Department of Biochemistry

Department of General surgery

Department of Diabtetology

\section{Study Population}

- 60 patients with newly diagnosed diabetes mellitus

- 60 patients with diabetic foot ulcers

- Sample size-120

\section{Exclusion Criteria}

Known case of CAD, Malignancy, other infectious diseases at the time of the study

\section{Study Period}

December 2017 to December 2018

Method of DATA Collection

Patients admitted in the male and female surgical wards and Diabetology OPD of Sree Gokulam Medical College and Research foundation. $5 \mathrm{ml}$ of blood collected in plain vacutainer and EDTA tubes for measurement of CRP and $\mathrm{HbA} 1 \mathrm{c}$ repectively, from the patients after getting written informed consent

CRP is determined by TURBILYTE-CRP, turbidimetric immunoassay and $\mathrm{HbA} 1 \mathrm{C}$ was determined by BIO-RAD D-10 HEMOGLOBIN TESTING SYSTEM, the program utilizes ionexchange high performance liquid chromatography (HPLC).

CRP level less than $0.6 \mathrm{mg} / \mathrm{dl}$ was considered negative and more than or equal to $0.6 \mathrm{mg} / \mathrm{dl}$ was considered positive. HbA1c level more than or equal to $6.5 \%$ was diagnostic of diabetes mellitus.

\section{Statistical Tools Applied}

The data obtained after estimation of analytes were statistically analyzed with Microsoft excel 
and SPSS software version 18.A probability value of less than 0.05 is considered as the threshold for statistical significance.

\section{Results}

Correlation between CRP and HBA1C in patients with diabetic foot ulcer when compared to the newly diagnosed diabetics

Table 1: Comparison of HBA1C based on CRP for different group by chi-square test

\begin{tabular}{|c|c|c|c|c|c|c|c|}
\hline \multirow{2}{*}{ Group } & \multirow{2}{*}{ HBA1C } & \multicolumn{2}{|c|}{ Negative } & \multicolumn{2}{|c|}{ Positive } & \multirow{2}{*}{$\chi^{2}$} & \multirow[b]{2}{*}{$\mathrm{p}$} \\
\hline & & frequency & Percent & frequency & Percent & & \\
\hline \multirow{2}{*}{$\begin{array}{ll}\begin{array}{l}\text { Diabetic foot } \\
\text { ulcer }\end{array} & \\
\end{array}$} & Normal & 1 & 50.0 & 1 & 50.0 & \multirow{2}{*}{0} & \multirow{2}{*}{0.962} \\
\hline & Diabetes range & 30 & 51.7 & 28 & 48.3 & & \\
\hline \multirow{2}{*}{$\begin{array}{l}\text { Newly diagnosed } \\
\text { diabetics }\end{array}$} & Normal & 3 & 100.0 & 0 & 0.0 & \multirow{2}{*}{0.63} & \multirow{2}{*}{0.427} \\
\hline & Diabetes range & 47 & 82.5 & 10 & 17.5 & & \\
\hline
\end{tabular}



Table 2: Correlation between CRP and HBA1C in patients with diabetic foot ulcer when compared to the newly diagnosed diabetics by Pearson's correlation

\begin{tabular}{|l|c|c|}
\hline Group & $\mathrm{r}$ & $\mathrm{p}$ \\
\hline Diabetic foot ulcer & -0.097 & 0.460 \\
\hline Newly diagnosed diabetics & -0.123 & 0.349 \\
\hline
\end{tabular}

Scatter diagram for CRP and HBA1C in patients with diabetic foot ulcer when compared to the newly diagnosed diabetics

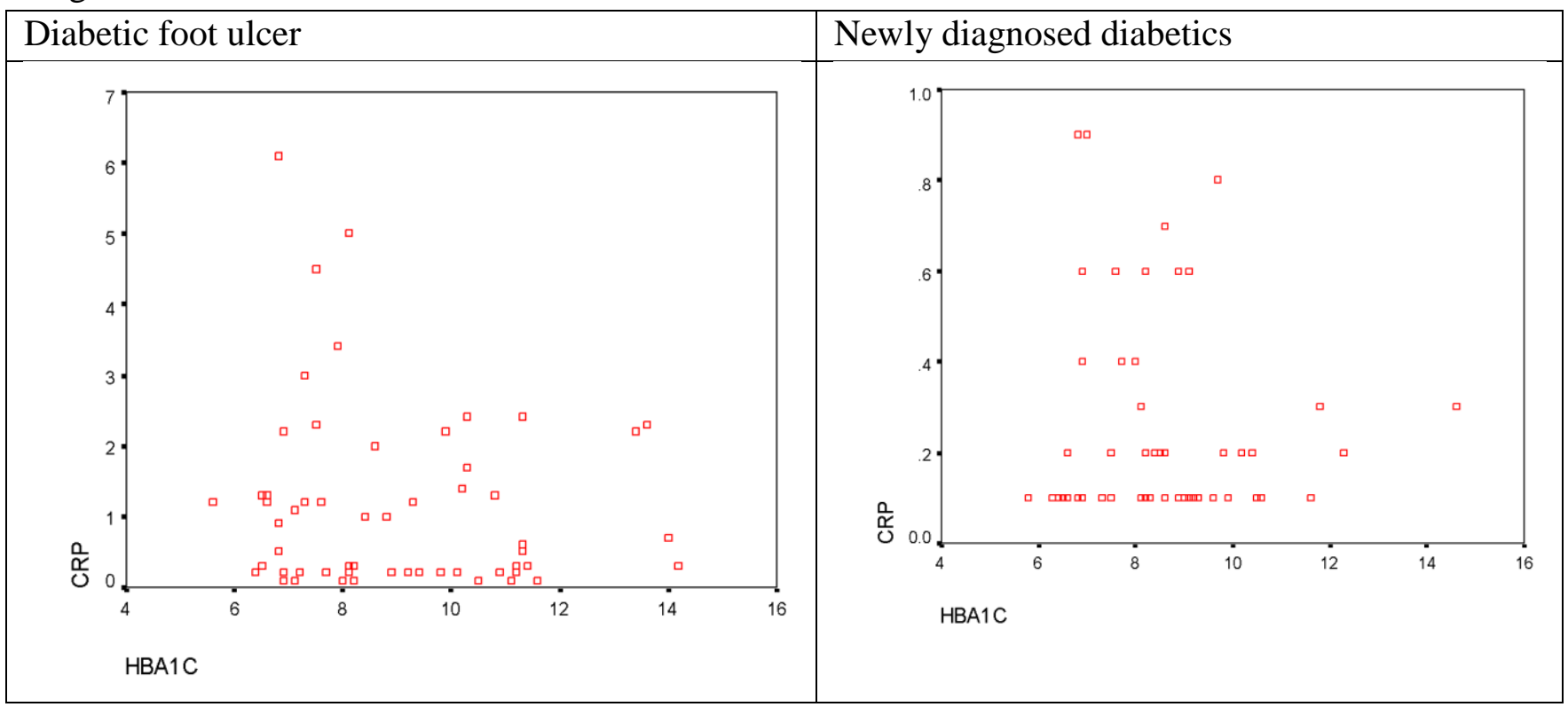




\section{Discussion}

C-reactive protein (CRP), a pentameric protein produced by the liver, has emerged as the golden marker for inflammation. Major role of CRP is in maintaining non-self recognition mediating innate immunity.CRP got its name as it was identified as a substance in patient's serum with acute inflammation that reacted with the antibody against the somatic capsular polysaccharide (Cpolysaccharide) of the bacteria pneumococcus. In many studies CRP levels have been higher in people with diabetes compared to those without diabetes. Less is known about whether CRP in people with diabetes is related to level of glycemic control. HbA1c is glycated hemoglobin, it is measured primarily to determine the threemonth average blood glucose level and can be used as a diagnostic test for diabetes mellitus and as an assessment test for glycemic control in people with diabetes.

After statistical analysis by chi-square test and Pearson's correlation there was no correlation found between CRP and HbAlc in both the groups, patients with newly detected diabetes and diabetic foot ulcers.

\section{Conclusion}

In this study serum CRP levels did not have any correlation with the HbA1c level in newly detected diabetes mellitus and in diabetic foot ulcer patients. These findings suggest there is no association between glycemic control and systemic inflammation in our study population. 